\title{
Development of Medical Countermeasures to Middle East Respiratory Syndrome Coronavirus
}

\author{
Timothy M. Uyeki, ${ }^{1}$ Karl J. Erlandson, George Korch, Michael O'Hara, Michael Wathen, \\ Jean Hu-Primmer, Sally Hojvat, Erik J. Stemmy, Armen Donabedian ${ }^{1}$
}

Preclinical development of and research on potential Middle East respiratory syndrome coronavirus (MERS-CoV) medical countermeasures remain preliminary; advancements are needed before most countermeasures are ready to be tested in human clinical trials. Research priorities include standardization of animal models and virus stocks for studying disease pathogenesis and efficacy of medical countermeasures; development of MERS-CoV diagnostics; improved access to nonhuman primates to support preclinical research; studies to better understand and control MERSCoV disease, including vaccination studies in camels; and development of a standardized clinical trial protocol. Partnering with clinical trial networks in affected countries to evaluate safety and efficacy of investigational therapeutics will strengthen efforts to identify successful medical countermeasures.

$\mathrm{F}$ rom September 2012 through April 27, 2016, a total of 1,728 laboratory-confirmed Middle East respiratory syndrome coronavirus (MERS-CoV) infections, leading to 624 deaths (36\% case-fatality proportion), had been reported to the World Health Organization (WHO) (1). Most infections (75\%) have been identified in Saudi Arabia (2). Zoonotic transmission from exposure to MERSCoV-infected Arabian camels, known as dromedaries, or their raw milk and limited, nonsustained human-to-human transmission have been reported, including large outbreaks in healthcare facilities (3-5). The recovery of infectious MERS-CoV in virus cultures of specimens from bed sheets, bedrails, intravenous fluid hangers, and radiograph equipment indicates the potential for fomite transmission of the virus in hospitals providing care for MERS-CoV patients (6). However, sustained human-to-human transmission has not been documented, and some case-patients have no identified source of exposure to MERS-CoV. As of April

Centers for Disease Control and Prevention, Atlanta, Georgia, USA (T.M. Uyeki); Office of the Assistant Secretary of Preparedness and Response, Washington, DC, USA (K.J. Erlandson,

G. Korch, M. O'Hara, M. Wathen, J. Hu-Primmer, A. Donabedian); Food and Drug Administration, Silver Spring, Maryland, USA

(S. Hojvat); National Institutes of Health, Rockville, Maryland, USA (E.J. Stemmy)

DOI: http://dx.doi.org/10.3201/eid2207.160022
2016, a total of 26 countries had reported locally acquired or exported cases from the Arabian Peninsula, including 2 cases in the United States identified during May 2014 in healthcare personnel who became ill after working in Saudi Arabia $(7,8)$. A traveler who visited Saudi Arabia, Qatar, the United Arab Emirates, and Bahrain and then returned to South Korea infected with MERS-CoV in mid-2015 triggered 184 MERS-CoV cases, resulting in 38 deaths in multiple health facilities and 1 additional case in a person who traveled to China $(9,10)$.

Human infections with MERS-CoV are expected to continue to occur on the Arabian Peninsula because of the prevalence of MERS-CoV in dromedaries and the cultural importance of these camels (i.e., for food, milk, and racing purposes) in the region. During the 2003 outbreak of severe acute respiratory syndrome (SARS) in China, civet cats, the suspected reservoir of SARS coronavirus (SARS$\mathrm{CoV}$ ), were culled aggressively; no outbreaks were identified after 2004. In contrast, culling of camels is culturally impractical in the Middle East, and MERS-CoV zoonotic infections of humans have continued since 2012.

The potential for emergence of MERS-CoV mutations that could facilitate sustained community transmission and global dissemination cannot be predicted. No vaccines against or specific treatments for human infection with SARS-CoV, MERS-CoV, or other coronaviruses have been approved. Since 2013, efforts have focused on furthering development of animal models, vaccines, and therapies against MERS-CoV $(11,12)$. In this report, we update the current state of development for MERS-CoV medical countermeasures, including regulatory challenges in the United States, and draw attention to areas in immediate need of increased infrastructure support for development of these countermeasures.

\section{Strategies for Potential Use of MERS-CoV Medical Countermeasures}

MERS-CoV infection could theoretically be prevented by vaccination, pre- or postexposure antiviral chemoprophylaxis, or passive immunoprophylaxis of persons in affected countries at increased risk for MERS-CoV exposure (e.g., healthcare personnel, persons who work with camels) or

${ }^{1}$ These authors contributed equally to this article. 
persons at higher risk for more severe disease, including persons $>65$ years of age and those with chronic medical conditions. Therapeutic drugs with specific activity against MERS-CoV (e.g., antiviral drugs, immunotherapeutic treatments) or that target the host immune response could be used for treatment of human illness caused by MERS$\mathrm{CoV}$ infection or for pre- or postexposure prophylaxis. Before human clinical trials of potential MERS-CoV medical countermeasures are started, proof-of-concept data must be obtained from in vivo studies of experimentally infected animals. Such data may indicate a product's potential efficacy and provide a mechanism for selection of available medical countermeasure candidates. In addition, MERS$\mathrm{CoV}$ vaccines could be developed for animals and used for vaccination of dromedaries on the Arabian Peninsula and in source countries for camel imports to the Horn of Africa to reduce MERS-CoV transmission among camels and possibly from camels to humans.

\section{Animal Models and Virus Strains}

Preclinical development of MERS-CoV medical countermeasures has been hindered by several factors, including limited data on the natural history of MERS-CoV infection in humans; the lack of a small animal model that is naturally susceptible to MERS-CoV; and the inability to consistently replicate severe human disease in MERS$\mathrm{CoV}$-infected nonhuman primates (NHPs). Another factor is limited access to clinical samples and recent virus isolates; for example, a MERS-CoV strain isolated from a patient in 2012, rather than a more recently isolated strain, is currently used by most investigators worldwide.

Small animal and NHP models are useful for testing potential medical countermeasures for efficacy (Table 1). Studies in mice, both dipeptidyl peptidase-4 (DPP4 or cluster differentiation 26) transduced and transgenic, and in rabbits, hamsters, and ferrets have been reviewed elsewhere $(16,20,21)$. These small animal models have been used for screening potential MERS-CoV medical countermeasures $(13,14,22)$.

The major NHP models under development include rhesus macaques and common marmosets $(17,18,23)$. Overall, common marmosets appear to be better suited than rhesus macaques for therapeutic studies designed to target severe disease because marmosets show slightly slower onset of illness and longer duration and severity of disease and their small size requires lower doses of therapeutic drugs. However, the marmoset model has not been standardized and is not consistent between laboratories $(18,24,25)$. Furthermore, the size of marmosets substantially limits sequential blood sampling for virologic or pharmacokinetic testing. Challenges to the development of NHP models include determination and standardization of the optimal MERS-CoV challenge dose and of the volume and route of exposure, as well as the limited availability of NHPs, especially marmosets.

Large animal models in development include camels and camelids such as alpacas $(19,26,27)$. These models may be vital in understanding the virology and immunology

\begin{tabular}{|c|c|c|c|}
\hline Source & Species & Genetic modification & $\begin{array}{ll}\text { Pathology } \\
\end{array}$ \\
\hline $\begin{array}{l}\text { Perlman Laboratory, University } \\
\text { of lowa, lowa City, IA }\end{array}$ & Mouse & $\begin{array}{l}\text { Expressing human } \\
\text { DPP4 from } \\
\text { adenovirus } 5 \text { vector }\end{array}$ & $\begin{array}{l}\text { Transient and localized expression of human DPP4, mild } \\
\text { infection (13) }\end{array}$ \\
\hline $\begin{array}{l}\text { University of Texas Medical } \\
\text { Branch, Galveston, TX }\end{array}$ & Mouse & $\begin{array}{l}\text { Knock-in of human } \\
\text { DPP4, constitutive } \\
\text { promoter }\end{array}$ & $\begin{array}{l}\text { Expression of human DPP4 throughout the animal, } \\
\text { including brain, resulting in relentless weight loss and } \\
\text { death within days postinfection (14) }\end{array}$ \\
\hline $\begin{array}{l}\text { Regeneron Pharmaceuticals, } \\
\text { Inc., Tarrytown, NY }\end{array}$ & Mouse & $\begin{array}{l}\text { Knock-in of human } \\
\text { DPP4, natural } \\
\text { promoter }\end{array}$ & $\begin{array}{c}\text { Stable expression of human DPP4 under a natural } \\
\text { promotor (e.g., limited to the lung, absent in the brain), with } \\
\text { viral replication and lung pathology (15) }\end{array}$ \\
\hline $\begin{array}{l}\text { NIAID Rocky Mountain } \\
\text { Laboratories, Hamilton, MT } \\
\text { USA; NIH/NIAID/Laboratory of } \\
\text { Infectious Diseases, Bethesda, } \\
\text { MD, USA }\end{array}$ & $\begin{array}{l}\text { New Zealand } \\
\text { white rabbit }\end{array}$ & Wild-type & $\begin{array}{l}\text { MERS-CoV spike protein binds wild-type rabbit DPP4 } \\
\text { molecule that allows for attachment and infection by } \\
\text { MERS-CoV; intranasal infection leads to mild pulmonary } \\
\text { disease and increased viral titers (16) }\end{array}$ \\
\hline $\begin{array}{l}\text { NIAID Rocky Mountain } \\
\text { Laboratories }\end{array}$ & $\begin{array}{l}\text { Rhesus } \\
\text { macaque }\end{array}$ & Wild-type & $\begin{array}{c}\text { Acute localized to widespread pneumonia with transient } \\
\text { clinical disease, similar to mild/moderate human MERS- } \\
\text { CoV cases; multifocal, mild to marked interstitial } \\
\text { pneumonia, with virus replication occurring mainly in } \\
\text { alveolar pneumocytes was observed without evidence of } \\
\text { systemic infection (17) }\end{array}$ \\
\hline $\begin{array}{l}\text { NIAID Rocky Mountain } \\
\text { Laboratories }\end{array}$ & Marmoset & Wild-type & $\begin{array}{l}\text { MERS-CoV spike protein binds wild-type marmoset DPP4. } \\
\text { Multiple routes of infection used; similar to more severe } \\
\text { human MERS-CoV cases; lethality observed (18) }\end{array}$ \\
\hline $\begin{array}{l}\text { NIAID Rocky Mountain } \\
\text { Laboratories }\end{array}$ & Dromedaries & Wild-type & $\begin{array}{c}\text { Infection studies in a small number of dromedaries } \\
\text { underway in a large animal BSL-3 facility in the United } \\
\text { States (19) }\end{array}$ \\
\hline
\end{tabular}


of MERS-CoV infection in dromedaries, a natural host. In addition, serologic evidence of MERS-CoV infection in alpacas has been reported in Qatar (28). Major gaps for all animal models include a lack of consensus and availability of the optimal animal model to replicate severe human illness from MERS-CoV infection; limited availability of currently or recently circulating MERS-CoV strains; the lack of understanding of clinically relevant symptoms that can be incorporated into clinical scores or used as a signal to begin treatment in animal models; and competition for funding, laboratory space, availability of animals, and expertise with other emerging or reemerging infectious diseases, such as Ebola virus disease and Zika virus disease.

\section{Diagnostic Devices}

Critical issues for facilitating appropriate clinical management of MERS-CoV cases and for implementing infection prevention and control measures in healthcare facilities is the prompt diagnosis of MERS-CoV infection and the monitoring of prolonged viral shedding in severely ill patients and their healthcare and family contacts. Outside of the United States, several commercial and in-house academic laboratory reverse transcription PCR (RT-PCR) molecular assays are available for research, diagnostic, and viral load monitoring purposes. These assays can measure MERS-CoV RNA in samples from symptomatic patients and their asymptomatic contacts. Contributing factors to recent large clusters of MERS-CoV infection in hospitals in Saudi Arabia and South Korea may be linked to inadequate infection-control procedures and prolonged shedding of MERS-CoV. MERS-CoV RNA has been detected for 24-31 days after onset of fever in hospitalized patients $(29,30)$.

The Secretary of the US Department of Health and Human Services declared a potential public health emergency on May 29, 2013, regarding MERS-CoV infection that could have a high potential to affect national security or the health and security of US citizens living abroad. The US Food and Drug Administration (FDA) subsequently issued an emergency use authorization to the Centers for
Diseases Control and Prevention (CDC) for an in vitro molecular diagnostic test to diagnose MERS-CoV infection in multiple types of clinical specimens from symptomatic patients. The use of this test was later expanded to include the ability to test asymptomatic contacts of a person infected with MERS-CoV who traveled from Saudi Arabia to the United States. The CDC made this test available to multiple US public health laboratories, the US Department of Defense, and WHO laboratories worldwide. Although the test has been distributed extensively, it is limited in terms of the CDC's ability to scale up the supply of reagents to support a surge in MERS-CoV cases in the United States and in other countries where the test has been made available. Therefore, an emergency use authorization was issued on July 17, 2015, for the commercially developed RealStar MERS-CoV RT-PCR Kit U.S. (Altona Diagnostics GmbH, Hamburg, Germany) for use in the in vitro qualitative detection of MERS-CoV RNA in tracheal aspirate or tracheal secretion samples (31). Although this commercial assay is a first step in bridging the diagnostic test availability gap in case of a surge scenario, the current coverage, at least in the United States, is insufficient until alternative, FDA-cleared commercial tests are available (Table 2).

A worldwide gap exists in the lack of readily available, simple, rapid, and accurate diagnostic tests for use in outpatient and inpatient clinical settings where the ability of the facility to use currently available, higher complexity molecular tests is limited. The lack of commercial development of MERS-CoV assays may be partially related to the limited availability of clinical specimens and MERS-CoV isolates from infected patients. Availability of serum specimens from RT-PCRconfirmed MERS-CoV patients who survived can help facilitate development of serologic tests. If paired acute and convalescent serum samples are available, serologic tests can be used to confirm MERS-CoV infection when viral shedding is not detectable, and for surveillance purposes such as measuring population exposures and immunity to MERS-CoV infection.

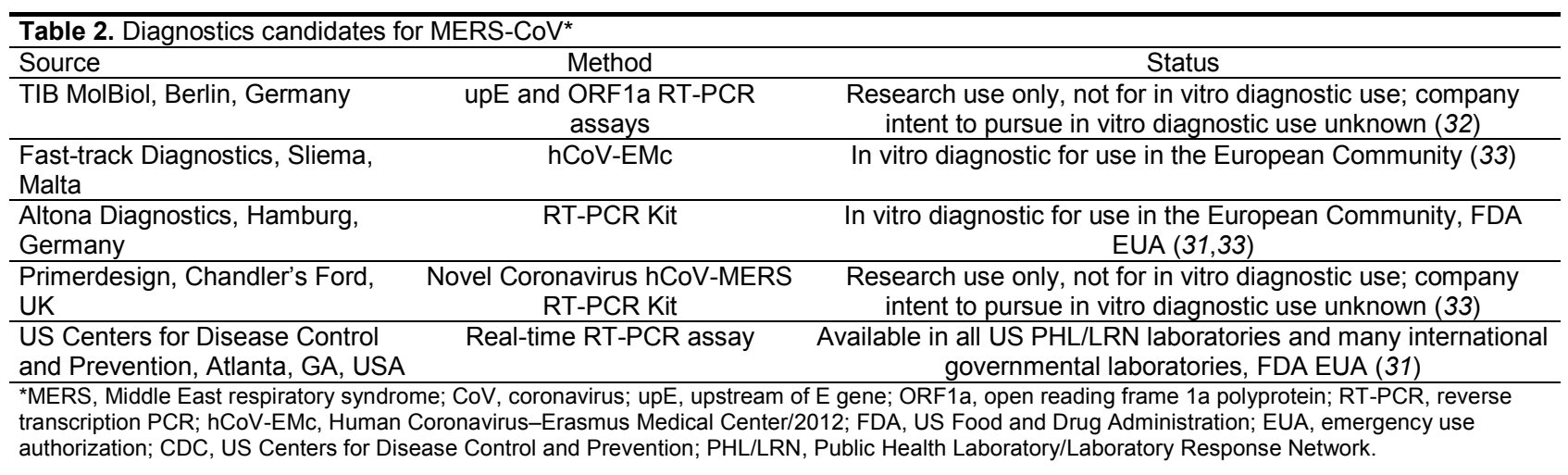




\section{Therapeutic Drugs}

No investigational therapeutic drugs have been evaluated for treatment of MERS-CoV patients in prospective randomized controlled clinical trials. Potential therapeutic drugs for MERS-CoV patients include available approved drugs with nonspecific properties, such as immunomodulators, small-molecule drugs with broad antiviral activity, repurposed FDA-approved small-molecule drugs that show activity against MERS-CoV in vitro (Table 3) $(34,35)$, and newly developed monoclonal or polyclonal antibody therapies with specific activity against MERSCoV (Table 4) (54).

One promising approach has been to investigate libraries of drugs approved by the FDA and the European Medicines Agency. Considering development times and manufacturing requirements for new products, repurposing of existing drugs might potentially facilitate a rapid response to outbreaks of emerging viruses (see Regulatory section for a discussion on repurposing). Other early-stage work on MERS-CoV therapeutics includes studies focusing on the essential viral replication steps of fusion, proteolysis, and RNA polymerization (Table 3) (54).

Immunotherapeutics under evaluation consist of convalescent plasma and monoclonal and polyclonal antibodies. Most of the monoclonal antibodies in development have specific neutralizing activity against the MERS-CoV spike protein $(55,56)$. Platforms are being developed to rapidly discover monoclonal antibodies, either from fully human convalescent blood or from transgenic animals, which can be manufactured on a large scale and are likely to have a good safety profile. The most advanced immunotherapeutic for MERS-CoV uses a transchromosomal bovine production system to produce fully human polyclonal MERS-CoV antibodies; a phase I study of this product was recently implemented (57; https://clinicaltrials.gov/ct2/ show/NCT02788188). Preliminary results from immunoprophylaxis or treatment studies have shown efficacy of fully human monoclonal or polyclonal antibodies in MERSCoV-infected mice and NHPs (Table 4). Although fully human monoclonal antibodies typically have a good safety

\begin{tabular}{|c|c|c|c|c|}
\hline Source & Drug & Target & $\begin{array}{l}\text { Anti-MERS-CoV } \\
\text { activity }\end{array}$ & Status \\
\hline $\begin{array}{l}\text { NIAID Rocky Mountain } \\
\text { Laboratories, Hamilton, MT, } \\
\text { USA }\end{array}$ & Ribavirin + IFN & $\begin{array}{l}\text { Polymerase }+ \\
\text { Immunomodulator }\end{array}$ & $\begin{array}{c}\text { Active in cell } \\
\text { culture and NHP }\end{array}$ & $\begin{array}{c}\text { Approved for hepatitis C virus, } \\
\text { compassionate use for MERS-CoV } \\
(36-38)\end{array}$ \\
\hline $\begin{array}{l}\text { University of Hong Kong, Hong } \\
\text { Kong }\end{array}$ & Interferon B1b & Immunomodulator & $\begin{array}{l}\text { Active in cell } \\
\text { culture }\end{array}$ & Preclinical development (24) \\
\hline $\begin{array}{l}\text { Hemispherix Biopharma, } \\
\text { Philadelphia, PA, USA }\end{array}$ & Alferon $\mathrm{N}$ & Immunomodulator & $\begin{array}{l}\text { Active in cell } \\
\text { culture }\end{array}$ & $\begin{array}{l}\text { Approved for human papillomavirus, } \\
\text { orphan drug designation granted by } \\
\text { the European Medicines Agency ( } 39 \text { ) }\end{array}$ \\
\hline $\begin{array}{l}\text { Romark Laboratories, Tampa, } \\
\text { FL, USA }\end{array}$ & Nitazoxanide & $\begin{array}{l}\text { Host functions, } \\
\text { glycosylation }\end{array}$ & $\begin{array}{l}\text { Active in cell } \\
\text { culture }\end{array}$ & $\begin{array}{c}\text { Approved for cryptosporidia and } \\
\text { giardia, in clinical trials for influenza } \\
\text { virus }(40)\end{array}$ \\
\hline AbbVie, North Chicago, IL, USA & Lopinavir & Protease & $\begin{array}{l}\text { Active in cell } \\
\text { culture, NHP } \\
\text { models }\end{array}$ & Approved for HIV (24) \\
\hline $\begin{array}{l}\text { BioCryst Pharmaceuticals, } \\
\text { Durham, NC, USA }\end{array}$ & BCX4430 & Polymerase & $\begin{array}{l}\text { Active in cell } \\
\text { culture and } \\
\text { (Ad5)-DPP4 } \\
\text { mouse }\end{array}$ & Clinical trial for Ebola virus (41) \\
\hline $\begin{array}{l}\text { Sarafianos Laboratory, } \\
\text { Columbia, MO, USA }\end{array}$ & SSYA10-001 & Helicase & $\begin{array}{l}\text { Active in cell } \\
\text { culture }\end{array}$ & $\begin{array}{l}\text { Broadly active against coronaviruses } \\
(42)\end{array}$ \\
\hline $\begin{array}{l}\text { Planet Biotechnology, Hayward, } \\
\text { CA, USA }\end{array}$ & $\begin{array}{l}\text { Immunoadhesin } \\
\text { (DPP4-Fc) }\end{array}$ & Spike/binding & $\begin{array}{c}\text { Active in cell } \\
\text { culture }\end{array}$ & Preclinical development (43) \\
\hline $\begin{array}{l}\text { New York Blood Center, New } \\
\text { York, NY, USA }\end{array}$ & HR2P-M2 & Spike/fusion & $\begin{array}{l}\text { Active in mouse } \\
\text { models }\end{array}$ & Preclinical development (44) \\
\hline $\begin{array}{l}\text { Loyola University, Chicago, } \\
\text { Stritch School of Medicine, } \\
\text { Maywood, IL, USA }\end{array}$ & $\begin{array}{l}\text { Protease } \\
\text { inhibitors }\end{array}$ & $\begin{array}{l}\text { MERS-CoV PLpro, } \\
\text { MERS-CoV } \\
\text { 3CLpro5 }\end{array}$ & $\begin{array}{l}\text { Active in cell } \\
\text { culture }\end{array}$ & Preclinical development (45) \\
\hline $\begin{array}{l}\text { University of Maryland, College } \\
\text { Park, MD. USA; Rega Institute, } \\
\text { Katholieke Universiteit Leuven, } \\
\text { Leiden, Belgium; NCATS; NIAID; } \\
\text { University of Leiden, South } \\
\text { Holland, the Netherlands }\end{array}$ & $\begin{array}{l}\text { FDA-approved } \\
\text { drug screens }\end{array}$ & $\begin{array}{l}\text { Multiple host } \\
\text { targets }\end{array}$ & $\begin{array}{l}\text { Active in cell } \\
\text { culture; } \\
\text { chloroquine and } \\
\text { chlorpromazine } \\
\text { are promising }\end{array}$ & Multiple screening efforts $(34,35)$ \\
\hline \multicolumn{5}{|c|}{$\begin{array}{l}\text { *MERS-CoV, Middle East respiratory syndrome coronavirus; NIAID, National Institute of Allergy and Infectious Diseases, National Institutes of Health; } \\
\text { IFN, interferon; NHP, nonhuman primate; DPP4, dipeptidyl peptidase-4; spike, MERS-CoV spike protein; PLpro, papain-like protease; 3CLpro, 3C-like } \\
\text { protease; NCATS, National Center for Advancing Translational Sciences, NIAID; FDA, US Food and Drug Administration. } \\
\text { †Christopher Bond Life Sciences Center, University of Missouri Department of Molecular Microbiology and Immunology, University of Missouri School of } \\
\text { Medicine. }\end{array}$} \\
\hline
\end{tabular}


Table 4. MERS-CoV immunotherapeutic treatment candidates*

\begin{tabular}{|c|c|c|c|c|}
\hline Source & Drug & Target & $\begin{array}{l}\text { Anti-MERS-CoV } \\
\text { activity }\end{array}$ & Status \\
\hline Multiple & IVIG & $\begin{array}{l}\text { Spike, } \\
\text { immune } \\
\text { system }\end{array}$ & Unknown & $\begin{array}{l}\text { Intravenous (VIG is available and has been } \\
\text { used for the treatment of } \geq 1 \mathrm{MERS}-\mathrm{CoV} \\
\text { patients with unknown clinical benefit (40). }\end{array}$ \\
\hline $\begin{array}{l}\text { King Abdullah International } \\
\text { Medical Research Center, } \\
\text { Riyadh, Saudi Arabia } \\
\end{array}$ & $\begin{array}{l}\text { Convalescent } \\
\text { serum }\end{array}$ & $\begin{array}{l}\text { Spike, } \\
\text { immune } \\
\text { system }\end{array}$ & $\begin{array}{l}\text { Ad5-DPP4 mouse } \\
\text { efficacy }\end{array}$ & $\begin{array}{l}\text { A pilot clinical trial of convalescent plasma } \\
\text { treatment of MERS-CoV patients is ongoing } \\
\text { but not recruiting in Saudi Arabia (46) }\end{array}$ \\
\hline $\begin{array}{l}\text { Sanford Applied } \\
\text { Biosciences, Sioux Falls, } \\
\text { SD, USA }\end{array}$ & $\begin{array}{l}\text { Transgenic bovine } \\
\text { polyclonal }\end{array}$ & Spike & $\begin{array}{l}\text { Ad5-DPP4 mouse } \\
\text { and NHP studies }\end{array}$ & Preclinical development (47) \\
\hline $\begin{array}{l}\text { National Cancer Institute, } \\
\text { NIH, Bethesda, MD, USA }\end{array}$ & M336, M337, M338 & Spike & $\begin{array}{l}\text { MERS-CoV } \\
\text { neutralization }\end{array}$ & Preclinical development (48) \\
\hline $\begin{array}{l}\text { Tsinghua University, } \\
\text { Beijing, China }\end{array}$ & MERS-4, MERS-27 & Spike & $\begin{array}{c}\text { MERS-CoV } \\
\text { neutralization }\end{array}$ & Preclinical development (49) \\
\hline $\begin{array}{l}\text { Dana Farber Institute, } \\
\text { Boston, MA, USA }\end{array}$ & $\begin{array}{c}\text { 3B11, 1F8, 3A1, } \\
80 \mathrm{R}\end{array}$ & Spike & $\begin{array}{c}\text { MERS-CoV } \\
\text { neutralization }\end{array}$ & Preclinical development (50) \\
\hline $\begin{array}{l}\text { New York Blood Center, } \\
\text { New York, NY, USA }\end{array}$ & Mersmab1 & Spike & $\begin{array}{c}\text { MERS-CoV } \\
\text { neutralization }\end{array}$ & Preclinical development (51) \\
\hline $\begin{array}{l}\text { Regeneron } \\
\text { Pharmaceuticals, } \\
\text { Tarrytown, NY, USA }\end{array}$ & $\begin{array}{l}\text { REGN3051, } \\
\text { REGN3048 }\end{array}$ & Spike & $\begin{array}{l}\text { MERS-CoV } \\
\text { neutralization and } \\
\text { humanized DPP4 } \\
\text { mouse studies }\end{array}$ & Preclinical development (22) \\
\hline $\begin{array}{l}\text { Juntendo University, } \\
\text { Tokyo, Japan }\end{array}$ & $2 \mathrm{~F} 9$ and $\mathrm{YS} 110$ & CD26 & VLP neutralization & Preclinical development (52) \\
\hline $\begin{array}{l}\text { Humabs Biomed SA, } \\
\text { Bellinzona, Switzerland }\end{array}$ & LCA60 & Spike & Ad5-DPP4 mouse & Preclinical development (53) \\
\hline
\end{tabular}

profile and a defined set of preclinical toxicology studies, challenges to development of immunotherapeutics include ensuring the absence of antibody-dependent enhancement of disease and reducing the risk for generation of escape mutant viruses that would be resistant to treatment.

\section{Vaccines}

\section{Human Vaccination}

Development of MERS-CoV candidate vaccines was initiated by the National Institute for Allergy and Infectious Diseases at the National Institutes of Health, academic investigators, and several companies (Table 5). Most candidate vaccines are still being evaluated in animal models. They have generally targeted the spike protein of MERS-CoV and are recombinant virus, subunit, DNA, or virus-like vector vaccines $(60,63-67)$. One live-attenuated MERS-CoV candidate vaccine is in early development (66). Preliminary studies for several other MERS-CoV vaccine candidates have been initiated, and early results demonstrate immunogenicity; 2 have progressed to NHP challenge, and a phase 1 clinical study in adults of 3 different doses of a DNA plasmid vaccine that expresses the MERS-CoV spike protein was started in January 2016 (61). Ongoing assessment of antigenic evolution of circulating MERS-CoV strains is essential for informing vaccine development (68).

A concern that must be addressed in the development of MERS-CoV vaccines is the potential for causing antibody-dependent enhancement of disease upon virus challenge, such as what was observed with a SARS-CoV candidate vaccine upon SARS-CoV challenge (69). The lack of a precedent of coronavirus vaccines for humans poses another challenge for the evaluation of MERS-CoV vaccines for humans, although vaccines against other animal coronaviruses are safe and in use in animals.

\section{Camel Vaccination}

Considering the cultural importance of dromedaries on the Arabian Peninsula for meat, milk, and racing, prevention of camel-to-camel MERS-CoV transmission and reduction of spread from dromedaries to humans by camel vaccination is being investigated by government, academic, and commercial investigators (Table 6). Young camels appear to be at high risk for MERS-CoV infection and could be a priority group for vaccination $(73,74)$; the loss of maternal MERS-CoV antibodies $\approx 5-6$ months after birth suggests a short time window for vaccination (75). A major challenge to this approach is that dromedaries can be reinfected with MERS-CoV; a study by Farag et al. found no correlation between MERS-CoV RNA levels and neutralizing antibodies in camels (76), suggesting that antibodies may not be protective against infection. Because older camels can be reinfected, a camel vaccination strategy may require multiple dosing and booster vaccination to increase effectiveness over time. Experimental MERS-CoV infection studies and vaccine studies of a small number of dromedaries have been conducted in large animal Biosafety Level 3 facilities 
Table 5. Human vaccine candidates for MERS-CoV targeting spike protein*

\begin{tabular}{|c|c|c|}
\hline Source & Vaccine & Status \\
\hline Novavax, Gaithersburg, MD, USA & $\begin{array}{l}\text { Spike protein trimer in } 40 \mathrm{~nm} \\
\text { particle; likely adjuvanted }\end{array}$ & Mouse immunogenicity shown (58) \\
\hline $\begin{array}{l}\text { NIAID/Vaccine Research Center, Bethesda, } \\
\text { MD, USA }\end{array}$ & $\begin{array}{l}\text { Two candidate vaccine } \\
\text { approaches: DNA spike prime- } \\
\text { S1 protein boost and S1 prime- } \\
\text { S1 boost }\end{array}$ & $\begin{array}{l}\text { Mouse and NHP immunogenicity shown; NHP2 } \\
\text { (macaque-radiological efficacy shown) (59) }\end{array}$ \\
\hline $\begin{array}{l}\text { GeneOne Life Science, Seoul, South Korea; } \\
\text { Inovio Pharmaceuticals, Plymouth Meeting, } \\
\text { PA, USA }\end{array}$ & $\begin{array}{l}\text { DNA expressing spike; } \\
\text { electroporation device }\end{array}$ & $\begin{array}{l}\text { Mouse, NHP, and camel immunogenicity shown; } \\
\text { NHP }^{2} \text { (viremia, lung pathology) (60); Phase I study } \\
\text { started (61) }\end{array}$ \\
\hline Greffex, Aurora, CO, USA & $\begin{array}{l}\text { Fully deleted adenovirus } \\
\text { packaging vector }\end{array}$ & Mouse immunogenicity (62) \\
\hline $\begin{array}{l}\text { Erasmus University Rotterdam, Rotterdam, } \\
\text { the Netherlands; University of Marburg, } \\
\text { Marburg, Germany; Ludwig-Maximilians } \\
\text { University, Munich, Germany }\end{array}$ & MVA vectored spike protein & $\begin{array}{l}\text { Mouse immunogenicity and protection shown; } \\
\text { clinical trials in planning stage }(63,64)\end{array}$ \\
\hline $\begin{array}{l}\text { New York Blood Center, New York, NY, USA; } \\
\text { Shanghai Medical College, Shanghai, China }\end{array}$ & $\begin{array}{l}\text { Spike receptor-binding domain } \\
\text { subunit vaccine }\end{array}$ & $\begin{array}{l}\text { Recombinant protein containing the } 377-588 \text {-aa } \\
\text { fragment of the S1 subunit (65) }\end{array}$ \\
\hline
\end{tabular}

in the United States and overseas (19). In addition, 3 doses of a DNA vaccine containing the MERS-CoV spike protein induced humoral immunity in dromedaries (60). In a recent study, a modified vaccinia virus Ankara vaccine that expresses the MERS-CoV spike protein was administered intranasally and intramuscularly to dromedaries; when challenged intranasally with MERS-CoV, vaccinated dromedaries had fewer signs of respiratory infection and lower MERS-CoV titers in the upper respiratory tract compared with unvaccinated dromedaries (77). Alpacas (New World camelids) are being investigated as a suitable proxy for camels because of the lack of available dromedaries in the United States, the high cost of acquiring dromedaries, and the relatively smaller size of alpacas $(26,27)$.

\section{Regulatory Considerations for Medical Countermeasures in the United States}

Regulatory considerations for MERS-CoV medical countermeasures in the United States are focused on a pathway to human clinical trials for drugs and vaccines through submission of investigational new drug applications. Investigational new drug submissions must adhere to requirements set forth in the Code of Federal Regulations, Title 21, Part 312 (21 CFR 312; http://www.ecfr.gov/cgibin/text-idx?tpl=/ecfrbrowse/Title21/21 cfr312_main_02. tpl)._Several guidance documents exist on the FDA website related to virology, microbiology, pharmacology and toxicology, and clinical and medical considerations (78). The most appropriate approval pathway is likely to be product-specific and will require consideration of existing product data, proposed intended use and population for use, and validated endpoints for efficacy predictive of clinical benefit, if any. Likewise, data needed for consideration of an emergency use authorization, including dose finding and dose ranging, duration, and safety, can be obtained through sources such as investigational new drug clinical trials.

Repurposing of drugs approved by the FDA for other illnesses for a MERS-CoV indication can potentially be expedited or accelerated if 1) the mechanism of action for antiviral activity is defined, 2) there is no change to the approved final drug form and route of administration, 3) dosing does not exceed the currently approved dose and duration for the currently indicated population and adequate pharmacokinetics data support this dosing, and 4) the risk-benefit profile is acceptable for the intended population and indication. For example, the risk-benefit profile for an approved drug with an oncology indication may be unacceptable if the drug is repurposed for administration to a healthy population for MERS-CoV postexposure prophylaxis. However, data requirements to initiate human trials will depend on the characteristics of the drug product and its intended use against MERS-CoV. As such, sponsors should consider prioritizing drug development on the basis of the totality of scientific evidence and merit of the drug alone, not on whether the drug has been previously approved.

In the absence of a standardized and accepted animal model that simulates human disease from MERS-CoV infection, it is unclear how the FDA may be able to expedite licensure or approval when data are lacking. The best approach may be collection of preclinical safety data and implementation of adaptive human clinical trials. This approach was taken for medical countermeasures in response to the 2013-2016 Ebola virus disease outbreak.

For diagnostic devices, the current emergency use authorization pathway serves as a fast approach to make products available for emergency public health purposes. After an emergency has been terminated, Premarket Notifications for these products should be submitted to FDA for a more thorough evaluation as $510(\mathrm{k}) \mathrm{s}$ (http://www.fda.gov/ 
Table 6. Camel vaccine candidates for MERS-CoV targeting spike protein*

\begin{tabular}{lcc}
\hline Source & Vaccine & Status \\
\hline USG/Academic Institution Consortium & Recombinant and inactivated whole virus & Camel vaccination \\
\hline $\begin{array}{l}\text { NIAID Rocky Mountain Laboratories, Hamilton, } \\
\text { MT, USA/Colorado State University, Fort Collins, } \\
\text { CO, USA }\end{array}$ & $\begin{array}{c}\text { Spike protein subunit vaccine/Advax } \\
\text { adjuvant (baculovirus expressed) }\end{array}$ & $\begin{array}{c}\text { Camel and alpaca vaccination studies } \\
(70,71)\end{array}$ \\
\hline $\begin{array}{l}\text { Erasmus University Rotterdam, Rotterdam, the } \\
\text { Netherlands; University of Marburg, Marburg, }\end{array}$ & MVA-vectored spike protein & Camel vaccination challenge studies \\
$\begin{array}{l}\text { Germany; Ludwig-Maximilians University, Munich, } \\
\text { Germany }\end{array}$ & & $(71,72)$ \\
\hline Novavax AB, Uppsala, Sweden & Spike nanoparticles with adjuvant likely & In preclinical development \\
\hline University of Pittsburgh, Pittsburgh, PA & Adenovirus vectored spike protein & In preclinical development (72) \\
\hline $\begin{array}{l}{ }^{*} \text { MERS-CoV, Middle East respiratory syndrome coronavirus; spike, MERS-CoV spike protein; USG, US government; NIAID, National Institute of Allergy } \\
\text { and Infectious Diseases, National Institutes of Health; MVA, modified vaccinia Ankara. }\end{array}$
\end{tabular}

MedicalDevices/ProductsandMedicalProcedures/DeviceAp provalsandClearances $/ 510 \mathrm{kClearances} /$ default.htm).

\section{Clinical Experience and Medical Countermeasure Trials}

The overarching goal for clinical research of MERS-CoV patients is to optimize clinical management and to identify effective therapies to improve survival. Although clinical data on some MERS-CoV patients have been published in case series $(58,79,80)$, there is a need for much more epidemiologic, clinical, virologic, and immunologic data to improve the limited understanding of the pathogenesis of MERS-CoV infection in humans. Gaps include information on viral load and duration of viral shedding in blood, urine, respiratory, and other clinical specimens from infected persons; understanding of the innate and adaptive immune response to MERS-CoV infection; pathology data on the distribution of MERS-CoV in respiratory and extrapulmonary tissues in fatal cases; information from autopsies of persons who died of MERS-CoV; and an overall improved understanding of the pathogenesis of MERS-CoV in humans. Only 1 study has investigated MERS-CoV infection in autopsy tissues of a patient who died from the disease (81). Collaborations are especially needed to pool and systematically collect serial clinical specimens from MERS-CoV patients for virologic, immunologic, and biomarker analyses to correlate with clinical illness, and to conduct long-term follow-up of survivors of severe disease (82-84). Detailed understanding of host factors and cofactors associated with disease severity from asymptomatic infection to fatal illness is needed. Efforts to promote international sharing of clinical specimens and MERS-CoV isolates are needed to foster development of diagnostics, therapeutics, and vaccines.

Use of standardized clinical data collection instruments and common biologic sampling protocols for serial prospective data collection will facilitate data pooling from MERS-CoV cases and comparisons across clinical sites and countries. Global collaborations among clinical networks are also needed to implement clinical trials, preferably randomized controlled clinical trials, of MERS-CoV investigational therapeutics $(82-85)$. Without an international agreement on protocols and systematic standardization of case reporting and data collection methods, haphazard or anecdotal reporting and analysis of disease course and outcome may continue. WHO and the International Severe Acute Respiratory and Emerging Infection Consortium are collaborating in adapting standardized protocols for controlled clinical trials for MERS-CoV (83).

\section{Timelines for Clinical Trials of Medical Countermeasures}

Prospective controlled clinical trials (ideally randomized clinical trials) of potential MERS-CoV therapies and vaccines in humans are needed urgently; however, there is uncertainty in estimating timelines for the development of potential MERS-CoV medical countermeasures because of the need to further characterize existing and new animal models, the unpredictability of demonstrating a favorable risk-benefit outcome during preclinical testing, and competition for resources with other emerging infectious diseases. In addition, the risk for antibody-dependent enhancement of disease may interrupt the timeline for conducting human clinical trials of MERS CoV vaccines and immunotherapeutics. Researchers of all potential MERS$\mathrm{CoV}$ medical countermeasures should have preclinical toxicology data available before initiating human clinical trials. Although animal efficacy data are not technically required before implementing human clinical trials of potential countermeasures, such data are considered important for identifying the most promising medical countermeasure candidates, justifying risk in human volunteers, and informing the design of future clinical studies. Timeframes for the production of specimen panels and repositories to aid commercial diagnostic development are also contingent on obtaining adequate funding and clinical samples.

\section{Conclusions}

Although preclinical development and research on potential MERS-CoV medical countermeasures has achieved appreciable progress to date, such development is preliminary, and substantive challenges must be overcome before most potential countermeasures are ready for human 
clinical trials. The only clinical trials of MERS-CoV medical countermeasures to date are phase I studies of 1 candidate vaccine and 1 immunotherapeutic that were both implemented in 2016 and are ongoing. Prioritization of animal models, standardization of representative virus strains, and establishment of clinical trial capabilities in areas where the virus is endemic among dromedaries are viewed as critical elements of effective MERS-CoV medical countermeasures development. Results of substantial progress in establishing the infrastructure and platforms for preclinical and advanced clinical development of countermeasures can serve as a model to enable more timely response to other emerging infectious diseases of global public health concern in the future.

\section{Acknowledgments}

We thank John Beigel, Wendy Carter, David Cho, Su-Young Choi, Eric Donaldson, Heinz Feldmann, Barney Graham, Lisa Hensley, Cynthia Kelley, Peter Miele, Vincent Munster, David Spiro, Kanta Subbarao, and Melissa Willis for participating in foundational discussions and for help assessing potential therapeutic drugs and methods; vaccines under development or investigation; timelines for animal studies; scale-up of medical countermeasures; when human trials are to be started; regulatory issues for investigational new drug (IND) and emergency use authorization (EUA) applications, and clinical studies; and safety issues and prioritization for clinical trials. We also thank Dean Erdman for insightful discussions on MERS-CoV diagnostic assay development, Rick Bright, Tom Dreier, and Byron Rippke for helpful commentary, and Thuy Phan for organizational assistance.

Dr. Uyeki is the Chief Medical Officer for the Influenza Division, National Center for Immunization and Respiratory Diseases, $\mathrm{CDC}$. His research interests are in the epidemiology and clinical management of influenza and emerging infectious diseases.

\section{References}

1. World Health Organization. Emergencies preparedness, response: Middle East respiratory syndrome coronavirus (MERS-CoV) Saudi Arabia. 2016 Apr 27 [cited 2016 Apr 27]. http://www.who.int/ csr/don/26-april-2016-mers-saudi-arabia/en/

2. World Health Organization. Summary of current situation, literature update and risk assessment [updated 2015 July 7 ; cited 2015 Aug 12]. http://apps.who.int//iris/bitstream/10665/179184/2/ WHO_MERS_RA_15.1_eng.pdf

3. Assiri A, McGeer A, Perl TM, Price CS, Al Rabeeah AA, Cummings DAT, et al. Hospital outbreak of Middle East respiratory syndrome coronavirus. N Engl J Med. 2013;369:407-16. http://dx.doi.org/10.1056/NEJMoa1306742

4. Oboho IK, Tomczyk SM, Al-Asmari AM, Banjar AA, Al-Mugti H, Aloraini MS, et al. 2014 MERS-CoV outbreak in Jeddah-a link to health care facilities. N Engl J Med. 2015;372:846-54. http://dx.doi.org/10.1056/NEJMoa1408636

5. Alraddadi BM, Watson JT, Almarashi A, Abedi GR, Turkistani A, Sadran M, et al. Risk factors for primary Middle East respiratory syndrome coronavirus illness in humans, Saudi Arabia, 2014. Emerg Infect Dis. 2016;22:49-55. Epub 2015 Dec 18.
6. Bin SY, Heo JY, Song MS, Lee J, Kim EH, Park SJ, et al. Environmental contamination and viral shedding in MERS patients during MERS-CoV outbreak in South Korea. Clin Infect Dis. 2016;62:755-60. http://dx.doi.org/10.1093/cid/civ1020

7. Bialek SR, Allen D, Alvarado-Ramy F, Arthur R, Balajee A, Bell D, et al. First confirmed cases of Middle East respiratory syndrome coronavirus (MERS-CoV) infection in the United States, updated information on the epidemiology of MERS-CoV infection, and guidance for the public, clinicians, and public health authorities-May 2014. MMWR Morb Mortal Wkly Rep. 2014;63:431-6.

8. Kapoor M, Pringle K, Kumar A, Dearth S, Liu L, Lovchik J, et al. Clinical and laboratory findings of the first imported case of Middle East respiratory syndrome coronavirus to the United States. Clin Infect Dis. 2014;59:1511-8. http://dx.doi.org/10.1093/cid/ciu635

9. World Health Organization. Middle East respiratory syndrome coronavirus (MERS-CoV) — Republic of Korea. 2015 Jul 21 [cited 2016 Jan 5]. http://www.who.int/csr/don/21-july-2015-mers-korea/en/

10. World Health Organization. Middle East respiratory syndrome coronavirus (MERS-CoV) — China. 2015 May 30 [cited 2015 Dec 21]. http://www.who.int/csr/don/30-may-2015-mers-china/en/

11. National Institutes of Health. Middle East respiratory syndrome coronavirus (MERS-CoV) research: current status and future priorities. 2013 Jun 24 [cited 2015 Dec 1]. http://www.niaid.nih. gov/about/organization/dmid/documents/mers-covmeeting.pdf

12. National Academies of Sciences, Engineering, and Medicine. 2016. Rapid medical countermeasure response to infectious diseases: enabling sustainable capabilities through ongoing public and private-sector partnerships. Workshop summary [cited 2016 Mar 17]. http://www.nap.edu/read/21809/chapter/1

13. Zhao J, Li K, Wohlford-Lenane C, Agnihothram SS, Fett C, Zhao J, et al. Rapid generation of a mouse model for Middle East respiratory syndrome. Proc Natl Acad Sci U S A. 2014;111:4970-5. http://dx.doi.org/10.1073/pnas.1323279111

14. Agrawal AS, Garron T, Tao X, Peng B-H, Wakamiya M, Chan T-S, et al. Generation of transgenic mouse model of Middle East respiratory syndrome-coronavirus infection and disease. J Virol. 2015 Jan 14;JVI.03427-14. http://dx.doi.org/10.1128/ JVI.03427-14

15. Pascal KE, Coleman CM, Mujica AO, Kamat V, Badithe A, Fairhurst J, et al. Pre- and postexposure efficacy of fully human antibodies against spike protein in a novel humanized mouse model of MERS-CoV infection. Proc Natl Acad Sci U S A. 2015;213:8738-43 http://dx.doi.org10.1073/pnas.1510830112

16. Houser KV, Gretebeck L, Ying T, Wang Y, Vogel L, Lamirande EW, et al. Prophylaxis with a Middle East respiratory syndrome coronavirus (MERS-CoV)-specific human monoclonal antibody protects rabbits from MERS-CoV infection. J Infect Dis. Epub 2016 Mar 3. http://dx.doi.org/10.1093/infdis/jiw080

17. de Wit E, Rasmussen AL, Falzarano D, Bushmaker T, Feldmann F, Brining DL, et al. Middle East respiratory syndrome coronavirus (MERS-CoV) causes transient lower respiratory tract infection in rhesus macaques. Proc Natl Acad Sci U S A. 2013;110:16598-603. http://dx.doi.org/10.1073/pnas.1310744110

18. Falzarano D, de Wit E, Feldmann F, Rasmussen AL, Okumura A, Peng X, et al. Infection with MERS-CoV causes lethal pneumonia in the common marmoset. PLoS Pathog. 2014;10:e1004250. http://dx.doi.org/10.1371/journal.ppat.1004250

19. Adney DR, van Doremalen N, Brown VR, Bushmaker T, Scott D, de Wit E, et al. Replication and shedding of MERS$\mathrm{CoV}$ in upper respiratory tract of inoculated dromedary camels. Emerg Infect Dis. 2014;20:1999-2005. http://dx.doi.org/10.3201/ eid2012.141280

20. Gretebeck LM, Subbarao K. Animal models for SARS and MERS coronaviruses. Curr Opin Virol. 2015;13:123-9. http://dx.doi.org/ 10.1016/j.coviro.2015.06.009 
21. Baseler L, de Wit E, Feldmann H. A comparative review of animal models of Middle East respiratory syndrome coronavirus infection. Vet Pathol. Epub 2016 Feb 11. http://dx.doi.org/ 10.1177/0300985815620845

22. Pascal KE, Coleman CM, Mujica AO, Kamat V, Badithe A, Fairhurst J, et al. Pre- and postexposure efficacy of fully human antibodies against spike protein in a novel humanized mouse model of MERS-CoV infection. Proc Natl Acad Sci U S A. 2015;112:8738-43. http://dx.doi.org/10.1073/pnas.1510830112

23. van Doremalen N, Munster VJ. Animal models of Middle East respiratory syndrome coronavirus infection. Antiviral Res. 2015;22:28-38. Epub 2015 Jul 16.

24. Chan JFW, Yao Y, Yeung ML, Deng W, Bao L, Jia L, et al. Treatment with lopinavir/ritonavir or interferon- $\beta 1 \mathrm{~b}$ improves outcome of MERS-CoV infection in a non-human primate model of common marmoset. J Infect Dis. 2015;212:1904-13. http://dx.doi.org/10.1093/infdis/jiv392

25. Johnson RF, Via LE, Kumar MR, Cornish JP, Yellayi S, Huzella L, et al. Intratracheal exposure of common marmosets to MERS-CoV Jordan-n3/2012 or MERS-CoV EMC/2012 isolates does not result in lethal disease. Virology. 2015;485:422-30.

http://dx.doi.org/10.1016/j.virol.2015.07.013

26. Adney D, Bielefeldt-Ohmann H, Hartwig A, Bowen RA. Infection, replication, and transmission of Middle East respiratory syndrome coronavirus in alpacas. Emerg Infect Dis. 2016 Jun. Epub 2016 Mar 4. http://dx.doi.org/10.3201/eid2206.160192

27. Crameri G, Durr PA, Klein R, Foord A, Yu M, Riddell S. Experimental infection and response to rechallenge of alpacas with Middle East respiratory syndrome coronavirus. Emerg Infect Dis. 2016 Jun. Epub 2016 Mar 7. http://dx.doi.org/10.3201/ eid2206.160007

28. Reusken CBEM, Schilp C, Raj VS, De Bruin E, Kohl RHG, Farag EABA, et al. MERS-CoV infection of alpaca in a region where MERS-CoV is endemic [letter]. Emerg Infect Dis. 2016 Jun. Epub 2016 Feb 16. http://dx.doi.org/10.3201/ eid2206.152113

29. Song JY, Cheong HJ, Choi MJ, Jeon JH, Kang SH, Jeong EJ, et al. Viral shedding and environmental cleaning in Middle East respiratory syndrome coronavirus infection. Infect Chemother. 2015;47:252-5. http://dx.doi.org/10.3947/ic.2015.47.4.252

30. Memish ZA, Assiri AM, Al-Tawfiq JA. Middle East respiratory syndrome coronavirus (MERS-CoV) viral shedding in the respiratory tract: an observational analysis with infection control implications. Int J Infect Dis. 2014;29:307-8. http://dx.doi.org/ 10.1016/j.ijid.2014.10.002

31. Office of the Commissioner. MCM Legal, Regulatory and Policy Framework-Emergency Use Authorization; Middle East respiratory syndrome coronavirus (MERS-VoV) EUS information [cited 2015 Oct 1]. http://www.fda.gov/EmergencyPreparedness/ Counterterrorism/MedicalCountermeasures/MCMLegalRegulatory andPolicyFramework/ucm182568.htm\#MERS

32. Corman VM, Müller MA, Costabel U, Timm J, Binger T, Meyer B, et al. Assays for laboratory confirmation of novel human coronavirus (hCoV-EMC) infections. Euro Surveill. 2012; 17:20334.

33. Pas SD, Patel P, Reusken C, Domingo C, Corman VM, Drosten C, et al. First international external quality assessment of molecular diagnostics for Mers-CoV. J Clin Virol. 2015;69:81-5. http://dx.doi.org/10.1016/j.jcv.2015.05.022

34. de Wilde AH, Jochmans D, Posthuma CC, Zevenhoven-Dobbe JC, van Nieuwkoop S, Bestebroer TM, et al. Screening of an FDA-approved compound library identifies four small-molecule inhibitors of Middle East respiratory syndrome coronavirus replication in cell culture. Antimicrob Agents Chemother. 2014; 58:4875-84. Epub 2014 May 19.

35. Dyall J, Coleman CM, Hart BJ, Venkataraman T, Holbrook MR, Kindrachuk J, et al. Repurposing of clinically developed drugs for treatment of Middle East respiratory syndrome coronavirus infection. Antimicrob Agents Chemother. 2014;58:4885-93. http://dx.doi.org/10.1128/AAC.03036-14

36. Falzarano D, de Wit E, Rasmussen AL, Feldmann F, Okumura A, Scott DP, et al. Treatment with interferon- $\alpha 2 b$ and ribavirin improves outcome in MERS-CoV-infected rhesus macaques. Nat Med. 2013;19:1313-7. http://dx.doi.org/10.1038/ nm.3362

37. Al-Tawfiq JA, Momattin H, Dib J, Memish ZA. Ribavirin and interferon therapy in patients infected with the Middle East respiratory syndrome coronavirus: an observational study. Int J Infect Dis. 2014;20:42-6. http://dx.doi.org/10.1016/ j.ijid.2013.12.003

38. Omrani AS, Saad MM, Baig K, Bahloul A, Abdul-Matin M, Alaidaroos AY, et al. Ribavirin and interferon alfa-2a for severe Middle East respiratory syndrome coronavirus infection: a retrospective cohort study. Lancet Infect Dis. 2014;14:1090-5. http://dx.doi.org/10.1016/S1473-3099(14)70920-X

39. European Medicines Agency. Public summary of opinion on orphan designation. Interferon alfa-n3 for the treatment of Middle East respiratory syndrome. 5 Jan 2016 [cited 2016 Mar 17]. http://www.ema.europa.eu/docs/en_GB/document_library/Orphan designation/2016/01/WC500199406.pdf

40. Stockman LJ, Bellamy R, Garner P. SARS: Systematic review of treatment effects. PLoS Med. 2006;3:e343. http://dx.doi.org/ 10.1371/journal.pmed.0030343

41. Warren TK, Wells J, Panchal RG, Stuthman KS, Garza NL, Van Tongeren SA, et al. Protection against filovirus diseases by a novel broad-spectrum nucleoside analogue BCX4430. Nature. 2014;508:402-5. http://dx.doi.org/10.1038/nature13027

42. Adedeji AO, Singh K, Kassim A, Coleman CM, Elliott R, Weiss SR, et al. Evaluation of SSYA10-001 as a replication inhibitor of SARS, MHV and MERS coronaviruses. Antimicrob Agents Chemother. Epub 2014 May 19 [cited 2014 May 22]. http://aac.asm.org/cgi/doi/10.1128/AAC.02994-14

43. Wycoff K, Maclean J, Belle A, Yu L, Tran Y, Roy C, et al. Anti-infective immunoadhesins from plants. Plant Biotechnol J. 2015;13:1078-93. http://dx.doi.org/10.1111/pbi.12441

44. Channappanavar R, Lu L, Xia S, Du L, Meyerholz DK, Perlman S, et al. Protective effect of intranasal regimens containing peptidic Middle East respiratory syndrome coronavirus fusion inhibitor against MERS-CoV infection. J Infect Dis. 2015;212:1894-903. http://dx.doi.org/10.1093/infdis/jiv325

45. Kilianski A, Mielech AM, Deng X, Baker SC. Assessing activity and inhibition of Middle East respiratory syndrome coronavirus papain-like and 3C-like proteases using luciferase-based biosensors. J Virol. 2013;87:11955-62. http://dx.doi.org/10.1128/ JVI.02105-13

46. ClinicalTrials.gov. Anti-MERS-COV convalescent plasma therapy [cited 2015 Aug 11]. https://clinicaltrials.gov/ct2/show/ NCT02190799

47. Shultz D. Cows with human chromosomes enlisted to fight hantavirus. Science. Epub 2014 Nov 25 [cited 2015 Aug 11. http://news.sciencemag.org/biology/2014/11/cows-humanchromosomes-enlisted-fight-hantavirus

48. Ying T, Du L, Ju TW, Prabakaran P, Lau CCY, Lu L, et al. Exceptionally potent neutralization of Middle East respiratory syndrome coronavirus by human monoclonal antibodies. J Virol. 2014;88:7798-7806. http://dx.doi.org/10.1128/JVI.00912-14

49. Jiang L, Wang N, Zuo T, Shi X, Poon KMV, Wu Y, et al. Potent neutralization of MERS-CoV by human neutralizing monoclonal antibodies to the viral spike glycoprotein. Sci Transl Med. 2014;6:234ra59. http://dx.doi.org/10.1126/scitranslmed

50. Tang XC, Agnihothram SS, Jiao Y, Stanhope J, Graham RL, Peterson EC, et al. Identification of human neutralizing antibodies against MERS-CoV and their role in virus adaptive 
evolution. Proc Natl Acad Sci U S A. 2014;111:E2018-26. http://dx.doi.org/10.1073/pnas.1402074111

51. Du L, Zhao G, Yang Y, Qiu H, Wang L, Kou Z, et al. A conformationdependent neutralizing monoclonal antibody specifically targeting receptor-binding domain in MERS-CoV spike protein. J Virol. 2014;88:7045-53. http://dx.doi.org/10/1128/JVI.00433-14

52. Ohnuma K, Haagmans BL, Hatano R, Raj VS, Mou H, Iwata S, et al. Inhibition of Middle East respiratory syndrome coronavirus infection by anti-CD26 monoclonal antibody. J Virol. 2013; 87:13892-9. http://dx.doi.org/10.1128/JVI.02448-13

53. Corti D, Zhao J, Pedotti M, Simonelli L, Agnihothram S, Fett C, et al. Prophylactic and postexposure efficacy of a potent human monoclonal antibody against MERS coronavirus. Proc Natl Acad Sci USA. 2015;112:10473-8. http://dx.doi.org/10.1073/ pnas. 1510199112

54. Zumla A, Chan JFW, Azhar EI, Hui DSC, Yuen KY. Coronaviruses - drug discovery and therapeutic options. Nat Rev Drug Discov. Epub 2016 Feb 12. http://dx.doi.org/10.1038/ $\operatorname{nrd} .2015 .37$

55. Johnson RF, Bagci U, Keith L, Tang X, Mollura DJ, Zeitlin L, et al. 3B11-N, a monoclonal antibody against MERS-CoV, reduces lung pathology in rhesus monkeys following intratracheal inoculation of MERS-CoV Jordan-n3/2012. Virology. 2016;490:49-58. http://dx.doi.org/10.1016/j.virol.2016.01.004

56. Ying T, Li H, Lu L, Dimitrov DS, Jiang S. Development of human neutralizing monoclonal antibodies for prevention and therapy of MERS-CoV infections. Microbes Infect. 2015;17:142-8. http://dx.doi.org/10.1016/j.micinf.2014.11.008

57. Luke T, Wu H, Zhao J, Channappanavar R, Coleman CM, Jiao JA, et al. Human polyclonal immunoglobulin $\mathrm{G}$ from transchromosomic bovines inhibits MERS-CoV in vivo. Sci Transl Med. 2016;8:326. http://dx.doi.org/10.1126/scitranslmed.aaf1061

58. Arabi YM, Arifi AA, Balkhy HH, Najm H, Aldawood AS, Ghabashi A, et al. Clinical course and outcomes of critically ill patients with Middle East respiratory syndrome coronavirus infection. Ann Intern Med. 2014;160:389-97. http://dx.doi. org/10.7326/M13-2486

59. Wang L, Shi W, Joyce MG, Modjarrad K, Zhang Y, Leung K, et al. Evaluation of candidate vaccine approaches for MERS-CoV. Nat Commun. 2015;6:7712. http://dx.doi.org/10.1038/ncomms8712

60. Muthumani K, Falzarano D, Reuschel EL, Tingey C, Flingai S, Villarreal DO, et al. A synthetic consensus anti-spike protein DNA vaccine induces protective immunity against Middle East respiratory syndrome coronavirus in nonhuman primates. Sci Transl Med. 2015;7:301ra132. http://dx.doi.org/10.1126/scitranslmed.aac7462

61. Clinical Trials.gov. Phase I, open label dose ranging safety study of GLS-5300 in healthy volunteers [cited 2016 Mar 17]. https://clinicaltrials.gov/ct2/show/NCT02670187?term= mers-cov\&rank $=7$

62. Greffex, Inc. MERS [cited 2015 Oct 1]. http://www.greffex.com/ vaccines/mers/

63. Song F, Fux R, Provacia LB, Volz A, Eickmann M, Becker S, et al. Middle East respiratory syndrome coronavirus spike protein delivered by modified vaccinia virus Ankara efficiently induces virus-neutralizing antibodies. J Virol. 2013;87:11950-4. http://dx.doi.org/10.1128/JVI.01672-13

64. Volz A, Kupke A, Song F, Jany S, Fux R, Shams-Eldin H, et al. Protective efficacy of recombinant modified vaccinia virus Ankara delivering Middle East respiratory syndrome coronavirus spike glycoprotein. J Virol. 2015;89:8651-6. http://dx.doi.org/10.1128/ JVI.00614-15

65. Wang L, Shi W, Joyce MG, Modjarrad K, Zhang Y, Leung K, et al. Evaluation of candidate vaccine approaches for MERS-CoV. Nat Commun. 2015;6:7712. http://dx.doi.org/10.1038/ncomms8712

66. Almazan F, DeDiego ML, Sola I, Zuniga S, Nieto-Torres JL, Marquez-Jurado S, et al. Engineering a replication-competent, propagation-defective Middle East respiratory syndrome coronavirus as a vaccine candidate. mBiol 2013;4:e00650-13. http://dx.doi.org/10.1128/mBio.00650-13

67. Zhang N, Channappanavar R, Ma C, Wang L, Tang J, Garron T, et al. Identification of an ideal adjuvant for receptor-binding domain-based subunit vaccines against Middle East respiratory syndrome coronavirus. Cell Mol Immunol. 2016;13:180-90. http://dx.doi.org/10.1038/cmi.2015.03

68. Agnihothram S, Gopal R, Yount BL, Donaldson EF, Menachery VD, Graham RL, et al. Evaluation of serologic and antigenic relationships between Middle Eastern respiratory syndrome coronavirus and other coronaviruses to develop vaccine platforms for the rapid response to emerging coronaviruses. J Infect Dis. 2014;209:995-1006. http://dx.doi.org/10.1093/infdis/jit609

69. Tseng CT, Sbrana E, Iwata-Yoshikawa N, Newman PC, Garron T, Atmar RL, et al. Immunization with SARS coronavirus vaccines leads to pulmonary immunopathology on challenge with the SARS virus. PLoS ONE. 2012;7:e35421. http://dx.doi.org/10.1371/ journal.pone.0035421

70. Dodge J. Camels emit dangerous MERS virus, CSU confirms. November 2014 [cited 2015 Oct 2]. http://source.colostate.edu/ camels-emit-mers/

71. Kupferschmidt K. MERS surges again, but pandemic jitters ease. Science. 2015;347:1296-7. http://dx.doi.org/10.1126/ science.347.6228.1296

72. Kim E, Okada K, Kenniston T, Raj VS, AlHajri MM, Farag EA, et al. Immunogenicity of an adenoviral-based Middle East respiratory syndrome coronavirus vaccine in $\mathrm{BALB} / \mathrm{c}$ mice. Vaccine. 2014;32:5975-82. http://dx.doi.org/10.1016/ j.vaccine.2014.08.058

73. Khalafalla AI, Lu X, Al-Mubarak AIA, Dalab AHS, Al-Busadah KAS, Erdman DD. MERS-CoV in upper respiratory tract and lungs of dromedary camels, Saudi Arabia, 2013-2014. Emerg Infect Dis. 2015;21:1153-8. http://dx.doi.org/10.3201/eid2107.150070

74. Hemida MG, Chu DKW, Poon LLM, Perera RAPM, Alhammadi MA, Ng H, et al. MERS coronavirus in dromedary camel herd, Saudi Arabia. Emerg Infect Dis. 2014;20:1231-4. http://dx.doi.org/10.3201/eid2007.140571

75. Meyer B, Juhasz J, Barua R, Das Gupta A, Hakimuddin F, Corman VM, et al. Time course of MERS-CoV infection and immunity in dromedary camels. Emerg Infect Dis. 2016 Dec [cited 2016 June 3]. http://dx.doi.org/10.3201/eid2212.160382

76. Farag EA, Reusken CB, Haagmans BL, Mohran KA, Raj V, Pas SD, et al. High proportion of MERS-CoV shedding dromedaries at slaughterhouse with a potential epidemiological link to human cases, Qatar 2014. Infect Ecol Epidemiol. 2015;5:28305.

77. Haagmans BL, van den Brand JMA, Raj VS, Volz A, Wohlsein P, Smits SL, et al. An orthopoxvirus-based vaccine reduces virus excretion after MERS-CoV infection in dromedary camels. Science. 2016;351:77-81. http://dx.doi.org/10.1126/science.aad1283

78. Food and Drug Administration. Guidances (Drugs) [cited 2015 Aug 11]. http://www.fda.gov/Drugs/GuidancecomplianceRegulatoryInformation/Guidances/default.htm

79. Saad M, Omrani AS, Baig K, Bahloul A, Elzein F, Matin MA, et al. Clinical aspects and outcomes of 70 patients with Middle East respiratory syndrome coronavirus infection: a single-center experience in Saudi Arabia. Int J Infect Dis. 2014;29:301-6. http://dx.doi.org/10.1016/j.ijid.2014.09.003

80. Assiri A, Al-Tawfiq JA, Al-Rabeeah AA, Al-Rabiah FA, Al-Hajjar S, Al-Barrak A, et al. Epidemiological, demographic, and clinical characteristics of 47 cases of Middle East respiratory syndrome coronavirus disease from Saudi Arabia: a descriptive study. Lancet Infect Dis. 2013;13:752-61. http://dx.doi.org/10.1016/ S1473-3099(13)70204-4

81. Ng DL, Al Hosani F, Keating MK, Gerber SI, Jones TL, Metcalfe MG, et al. Clinicopathologic, immunohistochemical, and ultrastructural 
findings of a fatal case of Middle East respiratory syndrome coronavirus infection in United Arab Emirates, April 2014. Am J Pathol. 2016;186:652-8. Epub 2016 Feb 5. http://dx.doi. org/10.1016/j.ajpath.2015.10.024

82. Chu H, Zhou J, Wong BHY, Li C, Chan JFW, Cheng ZS, et al. Middle East respiratory syndrome coronavirus efficiently infects human primary $\mathrm{T}$ lymphocytes and activates the extrinsic and intrinsic apoptosis pathways. J Infect Dis. 2016;90414. http:10.1093/infdis/jiv380

83. International Severe Acute Respiratory and Emerging Infection Consortium. Severe acute respiratory infection data tools [cited 2015 Aug 11]. https://isaric.tghn.org/protocols/severe-acuterespiratory-infection-data-tools/
84. Dunning JW, Merson L, Rohde GGU, Gao Z, Semple MG, Tran D, et al. Open source clinical science for emerging infections. Lancet Infect Dis. 2014;14:8-9 and.

85. World Health Organization. Clinical management of severe acute respiratory infection when Middle East respiratory syndrome coronavirus (MERS-CoV) infection is suspected. Interim guidance. Updated 2 July 2015 [cited 2015 Aug 11]. http://apps.who.int/iris/ bitstream/10665/178529/1/WHO_MERS_Clinical_15.1_eng.pdf

Address for correspondence: Timothy M. Uyeki, Centers for Disease Control and Prevention, 1600 Clifton Rd NE, Mailstop A20, Atlanta, GA 30329-4027; email: tuyeki@cdc.gov

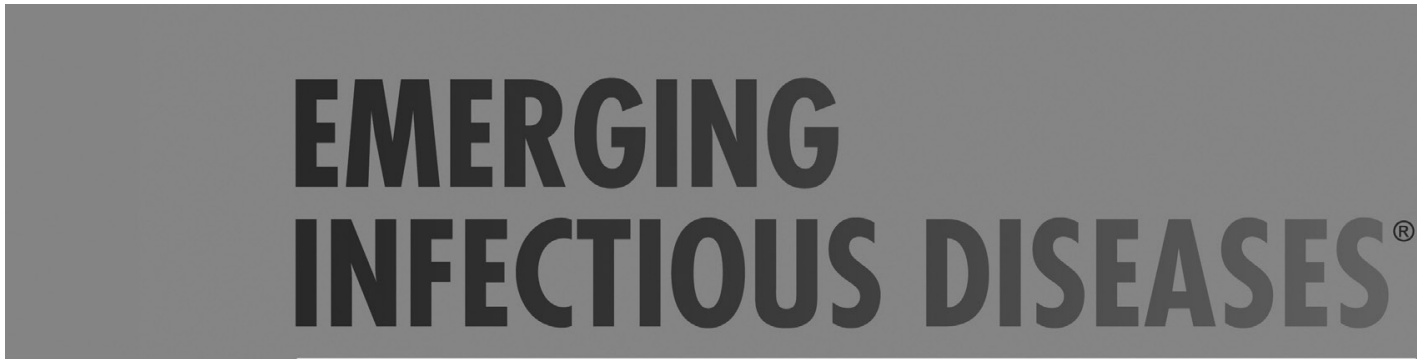

\section{JOURNAL BACKGROUND AND GOALS}

\section{What are "emerging" infectious diseases?}

Infectious diseases whose incidence in humans has increased in the past 2 decades or threatens to increase in the near future have been defined as "emerging." These diseases, which respect no national boundaries, include

$\star$ New infections resulting from changes or evolution of existing organisms

$\star$ Known infections spreading to new geographic areas or populations.

* Previously unrecognized infections appearing in areas undergoing ecologic transformation.

$\star$ Old infections reemerging as a result of antimicrobial resistance in known agents or breakdowns in public health measures.

\section{Why an "Emerging" Infectious Diseases journal?}

The Centers for Disease Control and Prevention (CDC), the agency of the U.S. Public Health Service charged with disease prevention and health promotion, leads efforts against emerging infections, from AIDS, hantavirus pulmonary syndrome, and avian flu, to tuberculosis and West Nile virus infection. CDC's efforts encompass improvements in disease surveillance, the public health infrastructure, and epidemiologic and laboratory training.

Emerging Infectious Diseases represents the scientific communications component of CDC's efforts against the threat of emerging infections. However, even as it addresses CDC's interest in the elusive, continuous, evolving, and global nature of these infections, the journal relies on a broad international authorship base and is rigorously peer-reviewed by independent reviewers from all over the world

\section{What are the goals of Emerging Infectious Diseases?}

1) Recognition of new and reemerging infections and understanding of factors involved in disease emergence, prevention, and elimination. Toward this end, the journal

$\star$ Investigates factors known to influence emergence: microbial adaptation and change, human demographics and behavior, technology and industry, economic development and land use, international travel and commerce, and the breakdown of public health measures.

* Reports laboratory and epidemiologic findings within a broader public health perspective.

$\star$ Provides swift updates of infectious disease trends and research: new methods of detecting, characterizing, or subtyping pathogens; developments in antimicrobial drugs, vaccines, and prevention or elimination programs; case reports.

2) Fast and broad dissemination of reliable information on emerging infectious diseases. Toward this end, the journal

* Publishes reports of interest to researchers in infectious diseases and related sciences, as well as to public health generalists learning the scientific basis for prevention programs.

$\star$ Encourages insightful analysis and commentary, stimulating global interest in and discussion of emerging infectious disease issues.

$\star$ Harnesses electronic technology to expedite and enhance global dissemination of emerging infectious disease information. 